\title{
EARLY 20TH-CENTURY WOODEN TENEMENT BUILDINGS IN ESTONIA: BUILDING BLOCKS FOR NEIGHBORHOOD LONGEVITY
}

\author{
Daniel B. Hess \\ University at Buffalo, School of Architecture and Planning, \\ State University of New York, USA \\ E-mail:dbhess@buffalo.edu \\ Submitted 01 February 2011
}

\begin{abstract}
During the early 20th century, the urban housing supply in Estonia expanded quickly to meet growing housing demand, resulting in tenement districts conceived for maximum profitability of rental units. In Karlova, a district near the city center of Tartu, about five hundred wooden houses, built between 1911 and the early 1920s and displaying simple Art Nouveau details, are set amid a charming district with a distinct milieu. This article focuses on three time periods during which the development of its built environment gave Karlova its distinctiveness: (1) the years leading up to World War I; (2) the interwar period; and (3) the two decades since 1991, or the post-transition period. Although the district was neglected during the Soviet era, it remains remarkably intact and has even experienced, since the 1990s, gentrification. The high-quality housing stock and charming built environment has much to offer to its diverse population of students, professionals, families, and longtime residents.
\end{abstract}

Keywords: wooden houses; Art Nouveau; Karlova; Tartu, Estonia; town planning.

\section{Introduction}

Karlova, a central residential district in Tartu, Estonia, contains a harmonious townscape of about five hundred early 20th-century Art Nouveau wooden tenement buildings. The built environment of the district is remarkably intact - few incursions from the mid- or late-20th century compromise its integrity - and it has, since the reestablishment of independence in Estonia in the early 1990s, experienced significant renovation. The district is admired by citizens and visitors alike for its striking composition of wooden homes, jumbled yards, gardens, sheds, streets and alleys, and smoke curling from chimneys.

The district is unique because its early 20th-century built form is largely intact, and a preserved historic manor house coexists within a townscape of wooden houses. The genotype that constitutes the built environment of the district - humble and sturdy buildings, efficient street layout, appealing density, proximity to the city center - has withstood Estonia's well-known political, economic, and social upheaval. This article develops a sequence of three time periods during which the development of its built environment gave Karlova its distinctiveness: (1) the years leading up to World War I; (2) the interwar period; and (3) the two decades since 1991, or the post-transition period following the reestablishment of independence in Estonia. During the Soviet occupation of Estonia between World War II and 1991, there was little change to the district's built form.

\section{Before World War I: Establishing a Homogeneous District of Unique Wooden Houses}

During a period of urbanization in the early 20 th century, Tartu, the intellectual and cultural center of Estonia and the financial and administrative hub of South Estonia, spread upon adjacent open space. ${ }^{1}$

\footnotetext{
Karlova became part of Tartu toward the end of the second decade of the 20th century. Tartu city government was at the time dominated by Baltic Germans as there was some initial resistance to annexing Karlova, which was home to many Estonian peasants relocating from the countryside to cities.
} 
The wooden houses of Karlova, were built quickly and inexpensively (Tohvri 1999) - on subdivided 18th-century manor land ${ }^{2}$ leased to the city (Udumäe 2010) within a decade beginning in 1911 (Siilivask 2002) to provide low-cost tenement housing for various classes of workers (see Fig. 1). Trade workers, craftspersons, and shopkeepers purchased the homes, and demand for rental housing units ensured the profitability of income housing. Ground floors could be used for commercial enterprises. City life held the promise of greater economic security than a rural life, despite only modest industry in Tartu. For peasants moving from the countryside, Karlova provided for its homogeneous residents a living atmosphere that was wholesome and comfortably connected to nature.

The houses display humble Art Nouveau detailing (often referred to in Estonia as Jugendstil), a style introduced about a decade before the first wooden buildings were erected in Karlova (Hallas 1999, 2002; Mansbach 2006; Tohvri 1999). Built during the "golden age of Tartu wooden architecture" (Siilivask 2002: 2), the homes feature simple timber-frame construction with exteriors usually painted in dark shades of brown, green, or gray (see Fig. 2). The design of many buildings is credited to Estonian engineer Fromhold Kangro (Siilivask 2002) and Baltic German and Russian engineers (Tohvri 1999) with execution by local builders. A nearby sawmill provided Karlova builders with high-quality timber that was, at the time, inexpensive (Siilivask 2002). Art Nouveau trimming perhaps inspired to an extent by the interior décor of

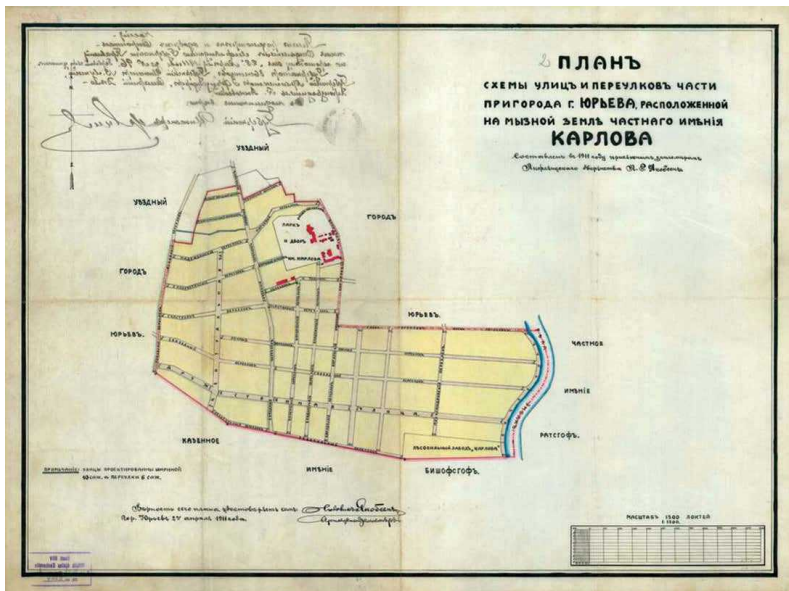

Fig. 1. This 1911 map shows the subdivision of the Karlova manor land to create streets for residential development. Source: Estonian Historical Archives, EAA 2623-1-2104. Reproduced courtesy of Estonian Historical Archives

\footnotetext{
2 Karlova is roughly bounded by Riia Street to the north, Tehase Street to the south, Turu Street to the east, and Vorru Street to the west.
}

the nearby manor house - is apparent in window and door surrounds and decorative gables. Most houses are austere and uniform in appearance, although elaborate detailing can occasionally be found. The homes have metal or tile roofs and decorated metal awnings. Height restrictions and a minimum distance of thirteen meters between buildings (or the use of a brick or stone firewall) were required by strict local building regulations (Tohvri 1999). ${ }^{3}$ After meeting the building regulations and fire safety code, the houses were conceived for maximum profitability of rental units (Tohvri 1999). Most importantly, the houses are highly functional, with plain but expressive decoration, designed for resourceful working-class residents.

\section{The Interwar Period: Beautification and a Milieu Develops}

Tenement buildings are subdivided into four, six, or eight flats in traditional arrangements, usually twoto five-room flats roughly fifty to sixty square meters in size (Tartu Linnavalitsus 2009). (There are a few single-family homes in the district.) When they were built, many of the flats shared toilets. A single shared water source was initially provided to the property, and residents carried water to individual units. By the 1930s, running water and sewers were plumbed to every flat, following electrification of the district in the 1920s (Tartu Linnavalitsus 2009). Then and now, the fireplace played a central role in the interior space, and most homes are still heated with wood fire.

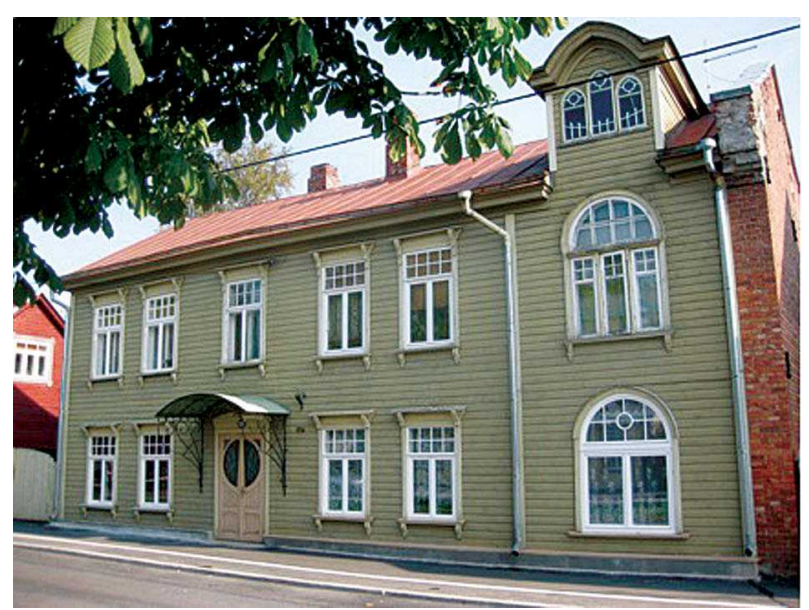

Fig. 2. A wooden house with Art Nouveau detailing on Kesk Street, 2010. Photo by Daniel B. Hess. @ Hess 2010

\footnotetext{
Such fire regulations were implemented in Estonia and Finland following fires in Russia during the 19th century in wooden housing districts.
} 
Houses are oriented, mostly without setback, in a transverse direction across shallow properties $(1,000$ to 3,000 square meters in size), parallel to the street right-of-way, producing the resemblance of a barracks and giving the townscape a "restless" (Siilivask 2002: 4) atmosphere. Most houses are built at the property line, although some are setback to form shallow foregardens. An occasional "rear house," where landowners lived while renting units to others in the main house, was situated at the rear of the property. The rustic timber houses sit upon low stone foundations; a buildup of street surface overlays and sidewalk overlays has given the appearance that certain houses have, over the years, "sunken" below grade. The streets follow a simple grid pattern, although some plots of land are irregularly shaped. Small gardens adjoin the homes; at one time the gardens were used to grow vegetables, but now most contain shrubs and ornamental fruit trees. Woodsheds, tool sheds, workshops, laundry rooms, and other outbuildings appear at the rear of properties (Hüvato 2008).

The built form of the district is highly traditional and centers upon a main axis, Tähe Street (see Fig. 3); the former neo-Gothic manor and adjacent park, situated on topographic high land, serves as a central organizing feature. The configuration of streets and pedestrian paths is not standardized and narrow street rights-of-way leave little or no room for pedestrian paths. Some streets lack sidewalks altogether, while others (Sõbra Street, for example) have generous (three-meterwide) sidewalks paved with asphalt. On Tähe Street, the sidewalks and carriageway are not arranged symmetrically within the public right-of-way; the result is a three-meter-wide paved sidewalk and two-meter-wide

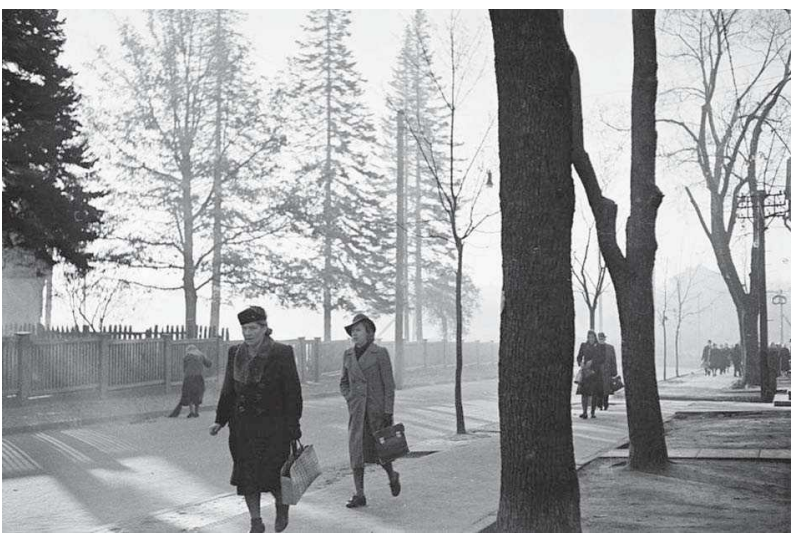

Fig. 3. Tähe Street became the central spine of the Karlova district during the Soviet period. Commuters walk amid allées of maple trees to the nearby city center, 1944. Source: photo by Karl Hintzer, 1944/1945, Herder Institute Marburg Photo Archive, 164385. Reproduced courtesy of Herder Institute Marburg treelawn on the west side of the street (which measures seven meters wide) and a two-meter-wide sidewalk with no treelawn on the east side. Main streets feature layers of asphalt atop original cobblestones; smaller side streets are unpaved.

Between World War I and World War II, there was modest beautification of the district to the degree that available resources allowed. The manor hill was developed into parkland, and property owners installed limestone-terraced gardens along sloping properties (Udumäe 2010). The municipal government installed allées of various tree species - which survive today and bestow unique natural settings on adjacent streets - including maple trees (Tähe Street), trimmed lime trees (Tolstoi Street), poplar trees (Kesk Street), and birch trees (Eha Street) (Fig. 4).

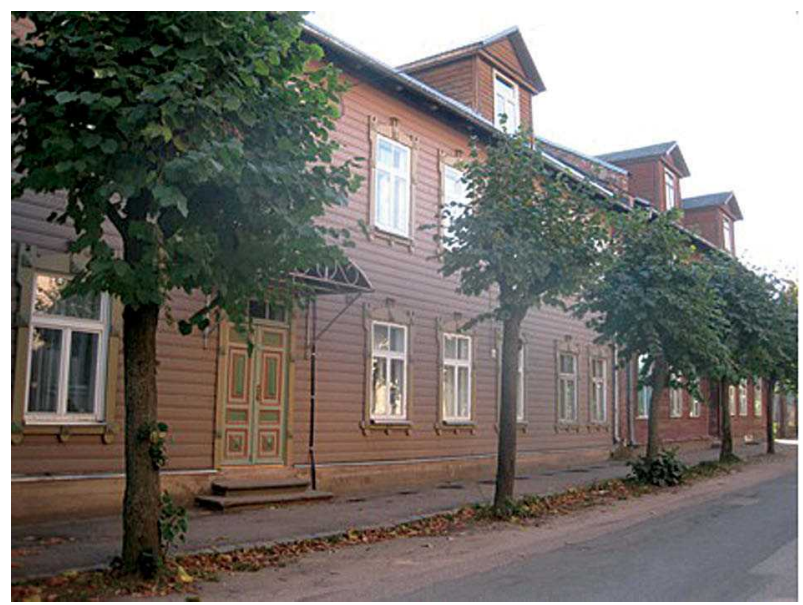

Fig. 4. Rows of trees separate the street from pedestrian paths. Photo by Daniel B. Hess. @ Hess 2010

\section{Post-Transition: Building Upon Assets and a Framework for Renewal}

Karlova holds unique appeal among varied communities within Tartu of German-inspired garden homes (Tammelinn), functionalist houses (Tähtvere), former villas (Ihaste), overwhelming tower-block modernist housing (Annelinn), and post-Soviet transition sprawl (Vadi) surrounding a traditional neoclassical centrum (French 1987; Pichler-Milanovich 1994; Tammaru 2001; Tarand 1976). Today, Karlova possesses only a few neighborhood services, including shops selling handiwork, churches, schools, a boutique hotel, and the manor house turned private residence. In past decades, there were more neighborhood shops - evidenced by chamfered building corners suggesting shop doors (now blockaded) on houses at intersections than now exist. Automobile ownership rates are higher than in past decades, and household consumption pat- 
terns now favor larger shopping centers located on the fringe of the city, resulting in a "value-free' landscape" in Karlova with few neighborhood shops and services (Haas 2006: 70).

Since the collapse of the former Soviet Union, the number of middle class who can afford homes has grown and Estonia has become a nation of homeowners (Lamine 2009), due to a post-transition housing restitution program, privatization of the housing system and withdrawal of state subsidies for housing, and tastes and preferences for owning rather than renting. Building preservation is a key concern for many residents, although those who strongly support renovation may lack sufficient resources to perform an authentic restoration using high-quality materials (Siilivask 2002). Nevertheless, typical renovations include structural repairs, new roofs, upgraded power, combination of smaller flats into larger flats, and new doors and windows (wooden replacements, although expensive, are preferred over lower-cost plastic or metal) (Hüvato 2008; Kruuse 2010). All renovations must be made in accordance with regulations set forth by the city government of Tartu, as buildings are registered with Tartu's cultural heritage inventory. The city government also supports the removal of inappropriate ancillary buildings, which unifies the townscape.

There are many assets in Karlova that can be emphasized in neighborhood renewal and community building. Most importantly, the district milieu provides a sense of place and continuity and evokes national fondness for pre - World War II Estonia. The density of Karlova is an asset for community development: it attracts people interested in living in a compact community and stands in contrast to Soviet-built districts that are less dense (Szelenyi 1996) and built on the periphery (Stanilov 2007), such as the bleak Tartu suburb of Annelinn. Although the notion of a detached suburban family home is appealing to many Estonians (Leetmaa, Tiit 2007), Karlova attracts those who treasure historic atmosphere. Many residents are committed to the preservation of individual properties and the integrity of the district. The district is able, because of its accessibility and supply of reasonably priced housing, to meet the needs of various groups - the young, the old, families, pensioners, and immigrants. In addition, the modestly sized dwelling units in Karlova have become more comfortable as average household size has decreased and incomes have increased (Statistics Estonia 2010).

During the period of Soviet occupancy of Estonia, there was little renovation of the district, because the Soviet housing system lacked a tradition of home maintenance and new housing construction - in di- rect support of industrial and military expansion - was favored over renovation of older districts (Haas 2006). Although the sturdy beam and frame construction of Karlova wooden homes is resilient, over time these buildings are vulnerable to a number of problems, including sagging, roof failure, moisture damage to windows and doors, and structural weakness or failure (Kruuse 2010). During the Soviet era, Karlova's wooden houses were not demolished (as in tenement districts that devolved into slums throughout Europe and the United States) perhaps because they were not considered blighted in the context of a centrally planned housing system and shortage economy (Aslund 2003).

Karlova was continuously occupied as a residential district and individual properties did not experience land use change to suit higher- or lower-order needs. However, one of the most significant changes to the landscape is the loss of some of the original wooden houses in a contiguous area during World War II bombing. ${ }^{4}$ Attention to district needs occurred at barely adequate levels throughout the middle part of the 20th century, however the constraints imposed by the Soviet housing allocation - and ensuing housing shortages - ensured that there was not significant decay or abandonment. According to the Soviet central housing allocation scheme, immigrants to Tartu between World War II and the late-1980s - mostly Russian-speaking arriving through official channels were usually assigned housing in newly built apartment houses (Kulu 2004). Thus, the continued occupancy of Karlova cannot be explained by the typical urban lifecycle phenomenon - urbanization, suburbanization, de-urbanization, re-urbanization - commonly understood to explain metropolitan form in Western cities (Van der Berg 1999). Instead, unique mechanisms insured that wooden houses remained occupied largely by people of Estonian descent. (Currently, 94 percent of Karlova residents are Estonian and 6 percent are ethnic minorities according to a 2008 housing satisfaction survey conducted by the Tartu city government).

During the Soviet era, central planning produced urban places that were uniform and homogeneous, and there was an explicit aim to provide equal access throughout all districts of a city and region to services that were intentionally undiversified owing to unifying state policy. In this egalitarian and homogenized

\footnotetext{
4 Forming a transition zone between Karlova and Tartu's old town is the northern section of Karlova. Wooden houses in this section of Karlova where lost when Tartu was bombed during World War II. Subsequently, during the Soviet period, Khrushchev-era five-story apartment buildings (Khrushchyovka) and wide streets (Riia) were added. Since Estonian Independence in 1991, this zone now includes shopping centers and high-rise office towers.
} 
landscape of Socialist cities (Smith 1996), the concept of "neighborhood" was weak (Robinson 2009). Although the housing allocation system "exacerbated and strengthened ethnic spatial separation" (Tammaru, Kontuly 2011: 2) of Estonians from Russian-speaking immigrants, the relative prestige of the tower block apartments into which many Russian-speaking immigrants settled has declined along with physical and social deterioration of the tower blocks (Enyedi 1998), and the prestige of pre-World War II districts has increased during the last two decades. This is perhaps a reflection of today's increased heterogeneity and diversity across townscapes in Estonia, in contrast to the preference for collectivity over individuality during the Soviet era (Andrusz 1987).

\section{A District Plan}

In 2009, Tartu city government adopted a district plan for Karlova (Tartu Linnavalitsus 2009), one of twelve city divisions designated in the 2005 Tartu comprehensive plan. During plan development, two opposing groups emerged: landowners wishing to build new apartment buildings and community advocates who sought to preserve the historic atmosphere, buildings, and green space.

The plan in general protects the milieu of buildings, streets, and gardens; celebrates the district's cultural heritage; and sets a course for continued renewal, giving special consideration to correction of arbitrary renovations shortly after Estonian independence that inadequately protected the integrity of buildings. The central feature of the planning document is a blockby-block inventory and condition report and plan for regular maintenance. Estonian law requires a detailed plan to be submitted and approved prior to the issuance of building permits for properties or groups of properties. Such plans, which become legal documents, establish zoning ordinances, define land use, describe building modifications, ensure environmental protection, and require compliance with other municipal guidelines, especially when exceptions to a comprehensive plan are desired (Lass 2000; Republic of Estonia 2002).

The very concept of a district plan is a significant departure from the Soviet imposition of homogeneity across townscapes. While the district plan begins to differentiate the unique character of Karlova from other places, as written it does not adequately articulate a vision of what Karlova can aspire to. Instead, the plan focuses on detailed inventories and condition reports. A visionary plan should employ broad thinking to identify particular problems and establish a more entrepreneurial approach to district renewal; Andrew
Isserman (Isserman 1985: 483), in a work titled "Dare to Plan," wrote that "planning voluntarily is sacrificing its role as visionary and idealist and is abandoning its responsibility to be a source of inspiration and ideas about what might be and what ought to be". Fewer than a dozen such comprehensive plans like the one produced for Karlova have been completed in Estonia in the last twenty years. As town planners and public officials throughout Estonia gain more experience with the process and more confidence - and more time elapses since the Soviet era of centralized planning for all enterprises - the quality of such plans will likely improve.

Certainly, there are stressors within the district. Roughly 70 to 80 percent of households have access to at least one vehicle; automobile storage is a challenge, since the district was built during pre-automobile times. The properties do not have driveways or garages, and most residents park their cars on streets, although street trees prevent parking in many places. In addition, available resources do not match individual and collective aspirations for the renewal of particular properties and the entire district.

\section{Conclusion}

Currently, Karlova is home to a diverse population of students, professionals, families, and longtime residents. New neighborhood amenities - though few in number - reflect present-day tastes and meet the demand for amenities and recreational facilities for individuals and families. These include a new playground in the shadows of St. Alexander's Orthodox Church on Sõbra Street and a bicycle lane in the protected center median of Kesk Street (see Fig. 5). At present, however, additional neighborhood markets and retail op-

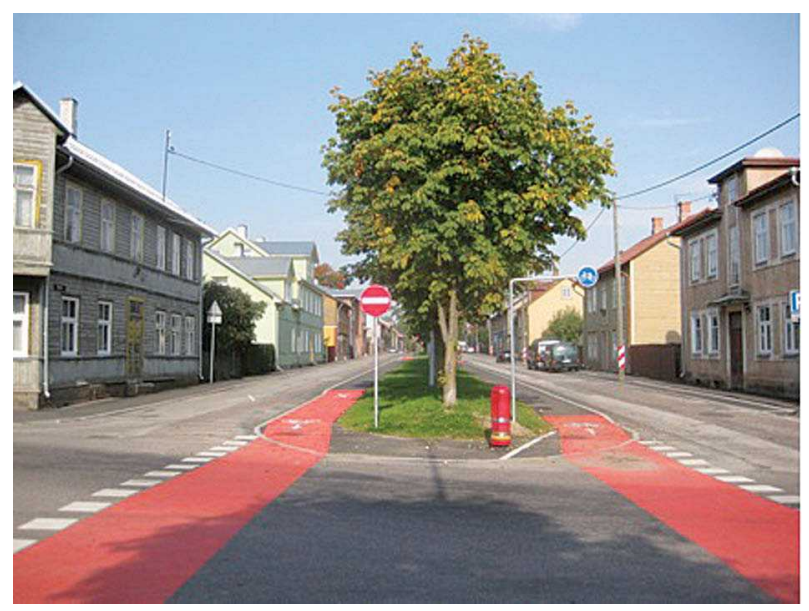

Fig. 5. Kesk Street is an important connector within the neighborhood. Bidirectional bicycle lanes were added in 2010 to the center five-meter-wide median. The street right-of-way measures sixteen meters. Photo by Daniel B. Hess. (c) Hess 2010 
portunities are needed within the district to enhance conveniences for residents. These will enrich the existing sturdy features of the neighborhood's buildings, streets, and green spaces. It is not difficult to imagine Karlova gentrifying in the future and transforming itself into a luxury housing district, with higher property values and the addition of boutiques and coffee houses on its charming streets and within its historic wooden houses, similar to Ålesund, Norway or Rauma, Finland (both UNESCO World Heritage Centers) or various districts in Riga or Brussels. The Karlova Society, a nonprofit neighborhood organization, may work to curb unwanted gentrification (or affect the pace, scale, or character of revitalization) if residents so desire and find a satisfactory balance between conservation and economic expansion.

\section{Acknowledgments}

When this research was conducted, Daniel B. Hess was a Fulbright Scholar at Tallinn University of Technology - Tartu College. The Fulbright Scholar program is sponsored by the U.S. Department of State and administered by the Council for International Exchange of Scholars, a division of the Institute of International Education. Mart Hiob, Edgar Kaare, Pille Metspalu, Sirle Salmistu, Epi Tohvri, and Kaisi Udumäe provided insights.

\section{References}

Andrusz, G. 1987. The Built Environment in Soviet Theory and Practice, International Journal of Urban and Regional Research 11(3): 478-498. doi:10.1111/j.1468-2427.1987.tb00063.x

Åslund, A. 2003. Building Capitalism. Cambridge, UK: Cambridge University Press.

Enyedi, G. 1998. Transformation in Central European Postsocialist Cities, in G. Enyedi (Ed.). Social Change and Urban Restructuring in Central Europe. Budapest: Akadémiai Kiadó.

French, R. 1987. Changing Spatial Patterns in Soviet Cities Planning or Pragmatism? Urban Geography 8(4): 309-320.

Gentile, M.; Tammaru, T. 2006. Ethnicity and Housing in the Post-Soviet City: Ust'-Kamenogorsk, Kazakhstan, Urban Studies 43: 1757-1778. doi:10.1080/00420980600838150

Haas, V. 2006. A Review of Urban Planning in Tallinn, Estonia: Post-Soviet Planning Initiatives in Historic and Cultural Context. Master's thesis. Ann Arbor, Michigan: University of Michigan.

Hallas, K. 1999. Wooden Architecture: History of Style, in K. Hallas (Ed.). Eesti Puit-Arhitektuur [Estonian Wooden Architecture]. Tallinn, Estonia: Museum of Estonian Architecture and Inspectorate of Antiquities of Estonia, 122-138.

Hallas, K. 2002. Art Nouveau Architecture: International Market and National Orientation in Estonia, Centropa 2(1): $13-20$.
Hüvato, M.-L. 2008. Pilpakülast saja aastaga nostalgiliseks Karlovaks, Tartu Postimees May 20.

Isserman, A. J. 1985. Dare to Plan: An Essay on the Role of the Future in Planning Practice and Education, Town Planning Review 56(4): 483-491.

Kruuse, K. 2010. Tudengid uurivad Karlova vanu maju, Tartu Postimees January 27.

Kulu, H. 2004. Determinants of First Residence and Migration in the Soviet Union after World War II: The Immigrant Population in Estonia, Environment and Planning A 36(2): 305-325. doi:10.1068/a35261

Lamine, B. 2009. Estonia: Analysis of a Housing Boom, ECFIN Country Focus. Economic Analysis from the European Commission's Directorate-General for Economic and Financial Affairs 4(7).

Lass, J. 2000. Compendium of Spatial Planning Systems in the Baltic Sea Region Countries. Prepared for Vision and Strategies around the Baltic (VASAB) 2010. Gdańsk, Poland.

Leetmaa, K.; Tammaru, T. 2007. Suburbanization in Countries in Transition: Destinations of Suburbanizers in the Tallinn Metropolitan Area, Geografiska Annaler, Series B: Human Geography 89: 127-146.

Mansbach, S. A. 2006. Modernist Architecture and Nationalist Aspiration in the Baltic: Two Case Studies, Journal of the Society of Architectural Historians 56(1): 92-111.

Pichler-Milanovich, N. 1994. The Role of Housing Policy in the Transformation Process of Central-East European Cities, Urban Studies 31(7): 1097-1115. doi:10.1080/00420989420080971

Republic of Estonia. Ministry of Environment. The Planning Act. Tallinn, Estonia: Riigiteataja, 2002.

Robinson, J. 2009. The Post-Soviet City: Identity and Community Development, Presented at City Futures in a Globalizing World: An International Conference on Globalism and Urban Change. June, 2009. Madrid, Spain.

Siilivask, M. 2002. Historic Town Structures of Tartu: A Historical Overview and Main Preservation Problems Today, Presented at the Workshop on Historic Structures, Advanced Research Initiation Assisting and Developing Networks in Europe. May.

Smith, D. M. 1996. The Socialist City, in G. Andrusz, M. Harloe, and I. Szelínyi (Eds.). Cities After Socialism: Urban and Regional Change and Conflict in Post-Socialist Societies. Oxford, UK: Blackwell.

Stanilov, K. 2007. The Restructuring of Non-Residential Uses in the Post-Socialist Metropolis, in K. Stanilov (Ed.). The Post-Socialist City: Urban Form and Space Transformations in Central and Eastern Europe after Socialism. Dordrecht, Netherlands: Springer.

Statistics Estonia [online], [retrieved November 23, 2010]. Available from Internet: $<$ http://www.stat.ee/ $>$.

Szelenyi, I. 1996. Cities Under Socialism - and After, in G. Andrusz, M. Harloe, and I. Szelenyi (Eds.). Cities After Socialism: Urban and Regional Change and Conflict in Post-Socialist Societies. Cambridge, MA: Blackwell Publishers.

Tammaru, T. 2001. Suburban Growth and Suburbanization Under Central Planning: The Case of Soviet Estonia, Urban Studies 38(8): 1341-1357. doi:10.1080/00420980120061061 
Tammaru, T.; Kontuly, T. 2011. Selectivity and Destinations of Ethnic Minorities Leaving the Main Gateway Cities of Estonia, Population, Space, and Place 17.

Tarand, K. 1976. Reader on the History of Estonian Urban Architecture. Tallinn, Estonia: Eesti NSV Haridusministeerium.

Tartu Linnavalitsus Karlova Miljööväärtusega Hoonestusala Kaitse - Ja Kasutamistingimused. Prepared by Hendrickson \& Ko. Tartu, Estonia: Tartu Linnavalitsuse Linnaplaneerimise Ja Maakorralduse Osakond.

Tohvri, E. 1999. Estonian Urban Wooden Areas: Their Formation and Type of Houses, in K. Hall (Ed.). Eesti Puit-Arhitektuur [Estonian Wooden Architecture]. Tallinn, Estonia: Museum of Estonian Architecture and Inspectorate of Antiquities of Estonia, 139-150.

Udumäe, K. 2010. Karlova mõisa lähiümbruse hoonestusala arhitektuurilised ja haljastuslikud elemendid 20. sajandi esimesel poolel [Architectural and landscape elements surrounding the Karlova manor during the first half of the 20th century. Master's thesis, Landscape Architecture Department]. Tartu, Estonia: Tallinn University of Technology, Tartu College.

Van den Berg, L. 1999. The Urban Life-Cycle and the Role of Market-Oriented Revitalization Policy in Western Europe, in A. Summers, P. Cheshire, and L. Senn (Eds.). Urban Change in the United States and Western Europe: Comparative Analysis and Policy. Washington, D.C.: Urban Institute Press, 539-558.

\section{A. DAUGIABUČIAI MEDINIAI NAMAI ESTIJOJE: GYVYBINGOS KAIMYNYSTĖS KVARTALAI}

\section{B. Hess}

Santrauka. Dvidešimtojo amžiaus pradžioje gyvenamųjų namų pasiūla Estijoje greitai augo atitikdama ị augančius gyvenamojo ploto poreikius. Minètos situacijos rezultatas - daugiabučių namų kvartalai sukurti taip, kad iš nuomojamų patalpų būtų gaunamas maksimalus pelnas. Karlova - kvartalas netoli Tartu centro. Jị sudaro apie penki šimtai medinių namų, pastatytų tarp 1911 ir 1920 metų. Pastatams būdingos paprastos Art Nouveau architektūrinès detalès, jie pastatyti išskirtinèje patrauklioje aplinkoje. Pateikiamame straipsnyje nagrinejami trys laikotarpiai, per kuriuos užstatymo kaita aptariamoje teritorijoje sukūrè išskirtinị jos tapatumą: 1) laikotarpis iki Pirmojo pasaulinio karo; 2) tarpukaris; 3) du dešimtmečiai po $1991 \mathrm{~m}$. Nežiūrint to, kad sovietiniais metais teritorija buvo nesaugoma ir ja nesirūpinama, Karlova išsaugojo nepažeistą architektūrinị urbanistinị vientisumą, o po $1990 \mathrm{~m}$. teritorijoje prasidejo gentrifikacijos procesai. Aukštos kokybès gyvenamasis užstatymas ir žavi urbanistine aplinka gali daug pasiūlyti ịvairioms gyventojų grupèms: studentams, profesionalams, šeimoms ir vyresnio amžiaus žmonèms.

Reikšminiai žodžiai: medinè architektūra, Art Nouveau, Karlova, Tartu, Estija, miestų planavimas.

\section{DANIEL B. HESS}

PhD, Associate Professor in the School of Architecture and Planning at the University at Buffalo, State University of New York, where he teaches studio-workshops and courses about urban history and urban planning practice. He earned a doctoral degree in Urban Planning from the University of California, Los Angeles. E-mail:dbhess@buffalo.edu

The author of numerous articles in leading urban planning journals, his research focuses on urban planning practice, and urban planning history, transport planning, and transportland use interactions. He received the Chester Rapkin Prize from the Association of Collegiate Schools of Planning for the Best Paper published in the Journal of Planning Education and Research and was awarded a fellowship from the U.S. National Endowment for the Humanities. 